Pamiętnik Literacki 2017, 4, s. 49-59
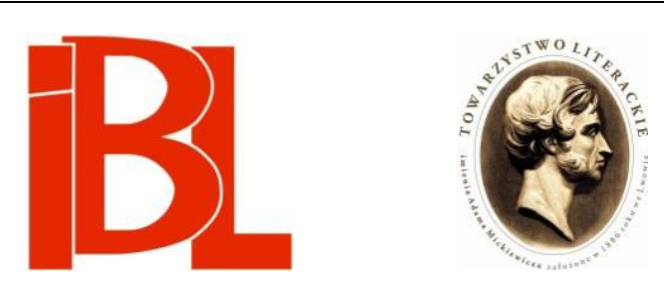

\title{
Twórczość prozatorska Edwarda Stachury w świetle tradycji literackiej i filozoficznej
}

Anna Al-Araj 
Pamiętnik Literacki CVIII, 2017, z. 4, PL ISSN 0031-0514

DOI:10.18318/pl.2017.4.4

ANNA AL-ARAJ Uniwersytet Jagielloński, Kraków

\section{TWÓRCZOŚĆ PROZATORSKA EDWARDA STACHURY W ŚWIETLE TRADYCJI LITERACKIEJ I FILOZOFICZNEJ}

Jest pisarz, więc należy mu wynaleźć drzewo genealogiczne ${ }^{1}$.

Zasadniczą motywacją do podjęcia namysłu nad charakterem twórczości prozatorskiej Edwarda Stachury jest przekonanie o niesprawiedliwości i pobieżności osądu - podzielanego przez wielu krytyków - na temat znaczenia dorobku tego pisarza. Jak zauważa Michał Januszkiewicz:

miejsce Edwarda Stachury [...] w powojennej literaturze polskiej nie wydaje się dziś jeszcze jasno określone: to twórca przez wielu badaczy albo pomijany, albo dość jednostronnie interpretowany ${ }^{2}$.

Wydaje się, że osobność i niemożność zaklasyfikowania dokonań autora Całej jaskrawości do któregokolwiek ze znanych nurtów znalazły przełożenie w przypisywaniu mu etykiet - w rodzaju: „św. Franciszek w dżinsach”3 czy „uśmiechnięty Dostojewski" ${ }^{4}$ - oraz w wygłaszaniu surowych ocen pod adresem maniery językowej Stachury; zarzucano mu m.in. „murzyńską składnię”:

Otóż pewni poeci najnowsi, obracający wokoło ciężki kamień problematyki „nowatorstwa językowego", przypominają mi po trosze mit dzikusa powieści podróżniczej i młodzieżowej na przełomie ubiegłego i naszego wieku. Jakieś takie $W$ pustyni i $w$ puszczy. Chodzi mi o mit języka oczywiście. Ten mit polegał na tym, że tacy na przykład Kali i Mea używają - gdy chodzi o czasowniki - jedynie bezokoliczników („Kali zrobić, widzieć, płakać...”) - upraszczając tym sposobem maksymalnie składnię niezrozumiałego i zbyt trudnego dla nich języka. To, co tam wynikało $z$ nieudolności, ma w naszej poezji wyniknąc z przer a fi n ow a n i a, z takiej znajomości języka, od której wychodząc - jako że nie może już być lepszej - z powrotem puszczamy się na wody wykoślawień, aby nadać wierszowi świeżość, egzotyczność brzmień $^{5}$.

1 E. St a chura, rękopis. Muzeum Literatury im. Adama Mickiewicza w Warszawie (dalej: Muz. Lit.), inw. 2551. Cyt. za: D. P a ch o cki, Stachura totalny. Lublin 2007, s. 21.

2 M. Januszki ewicz, Tropami egzystencjalizmu $w$ literaturze polskiej XX wieku. O prozie Aleksandra Wata, Stanisława Dygata i Edwarda Stachury. Poznań 1998, s. 177.

3 J. Z. Słojew ski (H a milt o n), Święty Franciszek $w$ dżinsach. „Kultura” 1966, nr 32, s. 12.

$4 \quad$ M. Szy bi st, Uśmiechnięty Dostojewski. „Życie Literackie” 1970, nr 6, s. 6.

5 J. Trzna del, Na marginesie. „Twórczość” 1963, nr 9, s. 64. Podkreśl. A. A.

Stachura odnosił się - w dość sarkastyczny sposób - do tych zarzutów zarówno na łamach utworów literackich, jak i w notatnikach: „A panowie krytycy łapali się za mądre głowy i mówili: co mają znaczyć te murzyńskości pana S.? "No, on przyjechał z Francji, to dobrze nie zna naszej pięknej polskiej mowy". A przecież chodziło wtedy Szeruckiemu o to samo, co mnie teraz. O wyplątanie języka z czasu, o wyprowadzenie go z czasu na cudowne manowce wieczystości. I kie- 
Mało kto dostrzegał w zabiegach stosowanych przez pisarza chęć stworzenia własnej - wymykającej się standardom literackim - poetyki oraz „dążenie do przywrócenia słowu jego żywej wyrazistości, która sprawniej funkcjonuje w codziennym użyciu niż w literaturze, wyjaławiającej ją sterylnymi konwencjami języka artystycznego" ${ }^{6}$. Wnikliwa interpretacja dzieł prozatorskich Steda oraz refleksja nad nimi skłaniają do wysunięcia hipotezy o niezwykłej spójności - tematycznej i formalnej - tej części jego dorobku. Jawi się Stachura jako autor dojrzały, świadomy swoich celów oraz zaznajomiony $\mathrm{z}$ osiagnięciami zachodnich myślicieli.

Mnogość inspiracji literackich i filozoficznych, jakie dostrzegalne są w utworach prozatorskich Stachury, stanowi potwierdzenie jego głębokiego zakorzenienia w tradycji zarówno europejskiego, jak i pozaeuropejskiego kręu kulturowego. Szczególnie wiele wątków, jak się wydaje, przejmuje Sted od amerykańskich transcendentalistów, których idee można łączyć m.in. z romantyczną krytyką rozumu. Trudno nie dostrzec zbieżności między postulatami wysuwanymi pod adresem uczonego przez Ralpha W. Emersona a refleksjami autora Całej jaskrawości na temat wartości książek:

Akt kreacji, akt myśli, uważany jest za święty, i świętość tę przenosi się na dzieło. [...] Stąd też, zamiast człowieka myślącego, mamy mola k siąż ko we go. Stąd też kasta uczonych w piśmie, która ceni księgi dla nich samych, a nie jako coś, co odnosi się do natury oraz człowieka, lecz jako swego rodzaju trzeci świat - obok świata i duszy. Stąd wreszcie konserwatorzy ksiąg, udoskonalacze tekstu i wszelkiego rodzaju bibliomani.

Książka to najlepsza z wszystkich rzeczy, gdy wła ś c i wi e z niej korzystać; nadużywana, należy do najgorszych. Na czym polega ów właściwy użytek? Czym jest ten jedyny cel, do którego prowadzą wszystkie środki? Otóż nie służą one niczemu poza in s p i a c j a. [...] Jedyną wartością w świecie jest a ktywny duch. Do takiej aktywności zobowiązany jest każdy człowiek; również i on ma w sobie takiego ducha, choć w przytłaczającej większości jest on u ludzi przytłumiony czy jeszcze nie narodzony${ }^{7}$.

- Czy w książkach jest mądrość?

- W książkach nie ma mądrości. Bo jeżeli jest, to ten, kto sam nie jest mądry, nigdy jej nie dojrzy. Będzie ją mieć przed samymi oczami, na samych oczach, lecz nie w oczach i dlatego jej nie zobaczy. Będzie po niej ślizgać się jak na łyżwach po lodzie. Będą podobać mu się przeróżne figury stylistyczne, metafory, porównania i temu podobne, ale nie będzie wiedzieć, o czym jest tekst. Będzie analizować, interpretować, komentować, filozofować, teologizować, egzegezować, ale te wszystkie poczynania, oczywiście, nie będą odczytaniem mądrości ${ }^{8}$.

Ta książka nie jest do przeczytania. Ta książka jest do odkrycia. Co jest w tej książce do odkrycia? [...] że każda książka jest zawsze tylko książką; że wszystkie słowa są zawsze tylko słowami, nigdy nie są tym, co - z mniejszym lub większym popisem - usiłują opisać9 .

dy teraz patrzę na te jego "murzyńskie" bezokoliczniki, to - to ja ci bić brawo, Szerucki, i ja tobie mówić: ty dobrze, o, jak dobrze ty pisać po polsku i w ogóle" (cyt. za: P a c h o c ki, op. cit., s. 142143. Podkreśl. A. A.). Warto zauważyć, że uprzywilejowanie bezokolicznikowej formy czasownika dotyczy u Steda przede wszystkim liryki, i to tej przynależącej do początkowego okresu jego twórczości.

$6 \quad$ M. Wó j c i k, Człowiek-nikt. Prozatorska twórczość Edwarda Stachury w kontekście buddyzmu zen. Kielce 1998, s. 148.

7 R. W. E me r s o n, Amerykański uczony. W: Natura. - Amerykański uczony. Przeł. M. Fili p czu k. Posł. P. Gu tow s ki. Kraków 2005, s. 54-55. Podkreśl. A. A.

8 E. St a ch ura, Fabula rasa. (Rzecz o egoizmie). Warszawa 1999, s. 54. Podkreśl. A. A.

9 Ibidem, s. 7. Analogiczne przemyślenia na temat „wiedzy książkowej” były udziałem A. Towiańskiego, który zwykł nazywać siebie „człowiekiem niepiśmiennym”, tj. „nieksiążkowym”. Wszelki skody- 
W przywołanych fragmentach pobrzmiewają echa romantycznej apologii „poezji czynnej”, której konsekwencję stanowi upatrywanie w słowie poetyckim siły oddziaływania magicznego - nie jest ono już jedynie nośnikiem informacji, staje się zaś strumieniem energii „wymierzonym” w umysł odbiorcy ${ }^{10}$. Mimo że trudno tu mówić o kontynuacji jakiejś jednej filozofii („z wieloznaczności tradycji romantycznej wynika konieczność ujęcia jej jako szeregu opozycji, uchwycenia jej dialogicznego i dramatycznego charakteru"11), można wskazać te elementy dystynktywne owej tradycji, które zostały wprowadzone w tekstach Stachury:

[są to:] postulat romantycznego indywidualizmu: kreacja bohatera romantycznego; centralny konflikt romantyczny: jednostka-świat; sposób rozumienia twórczości, roli artysty i sztuki jako „otwartej”, wieloznaczeniowej, niczym nie skrępowanej, odzwierciedlającej autentyczne ,ja” twórcy ${ }^{12}$.

Sted przejął ponadto od romantyków projekt walki z własnym ,ja”, skutkujący w jego przypadku „rozmyciem (w) się” i - w późniejszym czasie - powstaniem takiej idei jak człowiek-nikt ${ }^{13}$. Związany z przezwyciężeniem ego paradoks - polegający

fikowany system myślenia i wiedzy stanowił dla niego kolejną zasłonę ukrywającą światło „prawdy żywej” (K. Ru tk ow s ki, Projekt Stachury i cień Towiańskiego. „Nowy Wyraz” 1981, nr 1, s. 81). Przekonanie, że sztuka życia jest o wiele trudniejsza niż działalność literacka, podzielał także A. M i c ki e w i c z (Zdania i uwagi z dziet Jakuba Bema, Anioła Ślazaka 〈Angelus Silesius〉 i Sę-Martena. W: Dzieła wszystkie. T. 1, cz. 3: Wiersze 1829-1855. Oprac. Cz. Z gor z els ki. Wrocław 1981, s. 26), co ilustruje następujący fragment:

W słowach tylko chęć widzim, w działaniu potęgę,

Trudniej dzień dobrze przeżyć, niż napisać księgęe.

Jak zauważa Pachocki (op. cit., s. 62, przypis 127), „W notatnikach Stachury można odnaleźć ślady lektury pism Mickiewicza. Zob. zapis z 20 sierpnia 1973 r., Notatnik, t. 9, Muz. Lit., inw. 2551".

10 Zob. E. B alc e r za n, Magia słowa. W: Oprócz głosu. Szkice krytycznoliterackie. Warszawa 1971. W. Szy n g w els k i (Sobowtór w labiryncie. Proza artystyczna Edwarda Stachury. Warszawa 2003, s. 293) stwierdza, iż realizacja idei wiernego i zrozumiałego oddawania doznań w języku pojmowanym jako emisja energii psychicznej okazuje się dla Steda niemożliwa. $Z$ biegiem lat coraz dobitniej uświadamia on sobie, że literatura nie pozwala wyzwolić się z trywialnych ograniczeń komunikacji, czego poświadczeniem są konstatacje pojawiające się już w powieści E. S t a ch u ry Cała jaskrawość (Warszawa 1969, s. 202. Podkreśl. A. A.): „Cała jaskrawość można zobaczyć całym ciałem i całym tym, co nie jest ciałem. Całą jaskrawość można zobaczyć cała jaskrawością. $Z$ tego wynika jaskrawo, że kiedy mówię "zobaczyć", to jest to niedokładne. Całej jaskrawości się nie widzi, to znaczy nie tylko widzi, ale i słyszy, czuje, dotyka, smakuje, oddycha, śni, jawi, naw et rozumie. I tak dalej, i tak dalej. To wszystko $z$ osobna i jednocześnie”.

11 D. Patnikowska, Romantyzm $w$ literaturze polskiej XX wieku. W: Stownik literatury polskiej XX wieku. Red. A. Brodzk a [i in]. Wrocław 1992, s. 957.

12 Ibidem, s. 958. P a c h o cki (op. cit., s. 57) zwraca uwagę na liczne zbieżności między ideami głoszonymi przez Stachurę a postawą twórczą C. Norwida, przytaczając fragmenty komentarzy dotyczących dzieł Steda, jak np. ten z artykułu nieznanego autora O liryce E. Stachury (,Integracje” 1980, nr 8, s. 70-71. Podkreśl. A. A.): ,jest to odwołanie do Norwidowskiego pojmowania czynu jako związanego z etyką, c zynu twórcze go [...]”; „Bliska Norwidowi wydaje się u Stachury heroiczna łączność artysty i dzieła sztuki, bliskie przeświadczenie o pieśni jako pracy i jako ofi[erze]: "coś takiego jak u ujścia rzeki nurt powabny coś takiego jak rozlewnie krew płynąca z rany"". Cytat pochodzi z poematu E. S t a c h u ry Przystępuję do ciebie (Warszawa 1968). Warto wspomnieć, że romantyczne skłonności Stachury są równoważone przez wpływy awangardowe, zwłaszcza w postaci inspiracji dziełem J. Przybosia. Pa ch ocki (op. cit., s. 40) ujmuje ten problem w następujący sposób: „U Stachury widać przeplatanie się wpływów awangardowych 
na odczuciu społeczności poprzez odizolowanie się od własnego wnętrza - znany był także Adamowi Mickiewiczowi:

JA

Gdyby szatan na chwilę mógł wynijść sam z siebie,

To by w tej samej chwili już ujrzał się w niebie ${ }^{14}$.

JA

Muzyk zmięsza orkiestrę najlepiej dobraną,

Jeśli grając, stara się, żeby go słyszano ${ }^{15}$.

Stachurowe „Się” - stan kojarzony z przebudzeniem, otwarciem się na świat, zgodą na jego istnienie przy jednoczesnym odrzuceniu buntu - to nawiązanie (o charakterze polemicznym) do koncepcji Martina Heideggera ${ }^{16}$. Zbieżność idei głoszonych przez autora Bycia i czasu oraz Steda nie powinna dziwić, jak bowiem zauważa Januszkiewicz: „pisarz należał do tego pokolenia twórców, dla którego egzystencjalizm i płynące $z$ niego przesłania były czymś żywym, doświadczanym na co dzień” ${ }^{17}$. W ujęciu niemieckiego filozofa termin „Się” utożsamiany jest z anonimową opinią publiczną (systemem norm, reguł społecznych, określonych zachowań), anektująca jednostkę i ograniczająca jej odpowiedzialność za własne czyny:

Używamy sobie i bawimy się, tak jak s i ę używa; czytamy, patrzymy (i wydajemy sądy o literaturze i sztuce, tak jak s i ę patrzy i sądzi); równocześnie odsuwamy się od „tłumu”, tak jak s ię to zwykle robi; uznajemy za „oburzające” to, co si ę za oburzające uznaje ${ }^{18}$.

Postawy Stachury i Heideggera łączy przekonanie o wyróżniającym owo „Się” poczuciu harmonii i bezpieczeństwa. Podczas gdy w ujęciu Steda stanowi ono re-

i romantycznych. Trudno nie zauważyć korespondencji pomiędzy Stachurą i Przybosiem m.in. w kwestii "wszystkości» i w sposobie ujmowania czasu. Bliski Stachurze jest także postulat Awangardy o doskonaleniu warsztatu. Pisarze się znali, korespondowali, czasem widywali”.

Mickiewicz, op. cit, s. 28.

15 Ibidem, s. 32. Rozdarcie świata na ,ja” i nie-,ja”, typowe dla kultury europejskiej myślenie dualistyczne, jest, zdaniem Steda, podstawową przyczyną cierpień człowieka, uniemożliwiającą mu zrozumienie samego siebie i przysłaniającą ogrom świata. W notatniku S t a c h u ry (t. 12. Podkreśl. A. A.) pod datą 19 IX 1974 znajduje się następujący wpis: „Gdybyż mógł c zło w i e k w e w n ę tr zny i człowiek zewnętrzny - stanowić jedno. Sokrates".

16 Heidegger przejął to pojęcie („das Man”) od S. Ki r rkega ard a (Albo-albo. T. 2. Przeł. K. To eplitz. Warszawa 1976, s. 100-101), nadał mu jednak wyraźnie ontologiczne nacechowanie. Stąd też, jak zauważa J a n u s z k i e w i c z (op. cit., s. 49), nieuprawnione jest przypisywanie Heideggerowskiemu „Się” wykładni etycznej, o czym świadczy następująca uwaga niemieckiego filozofa (M. H e i d e g g e r, List o humanizmie. W: Znaki drogi. Przeł. S. Bl a n d zi [i in]. Warszawa 1995, s. 132. Podkreśl. A. A.): „To, co powiedzieliśmy w [książce] Bycie i czas [...] o "Się", w żadnym wypadku nie może być jedynie jakimś pobieżnym przyczynkiem do socjologii. "Się" n i e je s t również negatywem autentycznego sposobu bycia osoby, pojętym etycznie iżyciowo [existenziell]".

17 J a nu szkiewicz, op. cit., s. 33. Jak wiadomo, Heidegger ostro protestował przeciw uznawaniu go za egzystencjaliste - chciał, aby mianować go raczej ontologiem fundamentalnym. Przyjęcie - za Januszkiewiczem - określonej perspektywy badawczej, traktującej egzystencjalizm nie jako nurt filozoficzny, lecz jako szczególnego rodzaju światopogląd, wrażliwy na sprawy człowieka, „rzuconego-w-świat” i zagrożonego przez kulturę i postęp cywilizacyjny, pozwala jednak podtrzymać zaproponowane w niniejszym artykule stanowisko. Zob. też J. S a dzi k, Inne niebo, inna ziemia. W: Cz. Miło s z, Ziemia Ulro. Kraków 1994.

18 M. Heidegger, Bycie i czas. Przeł., przedm., przypisy B. B a ra n. Warszawa 1994, s. 180-181. 
zultat uwolnienia, osiągnięcia jedności ze światem, sytuującym się ponad podmiotowo-przedmiotowym podziałem, dla niemieckiego filozofa jest konsekwencją bezruchu, nawyku, egoizmu i rutyny - właściwym zautomatyzowanemu bytowaniu:

Pewność siebie i stanowczość Się szerzy rosnące przekonanie o zbędności właściwego rozumienia. Mniemanie tego Się, że dostarcza ono strawy i przewodzi pełnemu i prawdziwemu „Życiu”, wnosi w jestestwo us pokojenie, dla którego wszystko jest „w najlepszym porządku”, a wszystkie drzwi stoja otworem. Karząc samo siebie, upadające bycie-w-świecie samo siebie zarazem u s p o k a j a ${ }^{19}$.

Ważnym czynnikiem umożliwiającym Stachurze kształtowanie materii słownej dzieł prozatorskich na wzór poezji jest - odgrywający doniosłą rolę w jego twórczości - rytm. Występowanie tego elementu pozwalają wyeksponować m.in. takie środki poetyckie, jak zdecydowana dominacja grup trocheicznych i amfibrachicznych, wieloelementowe ciagi monopodyczne czy specyficzne układy grup akcentacyjnych w tekście ${ }^{20}$. Konsekwencje intensywnej rytmizacji języka mogą być rozmaite: doprowadza ona do częściowego wyzwolenia dzieła literackiego z konwencjonalności (eurytmia tekstu stanowi odniesienie do wewnętrznego rytmu człowieka, dlatego pozwala na zbliżenie domeny artystycznej i samej rzeczywistości), chroni obraz słowny przed „cywilizacyjnym zautomatyzowaniem” (rytm „przynosi ten porządek, który, będąc formą kształtowania stosunków pomiędzy rzeczami, zawsze pozostaje żywy i nigdy nie przekształca się w schemat" ${ }^{21}$ ), wprowadzając jednocześnie ład w dziedzinę języka i w dziedzinę rzeczywistości powołanej przez ów język do życia. Jak zauważa Mirosław Wójcik: „obciążenie wypowiedzi redundatywnymi walorami rytmu może być wyrazem chęci r e k o m p e n s a ty w planie językowym braku ładu lub celowości w świecie pozaliterackim" 22 . Rytm bowiem zmienia to, co nietrwałe i chwilowe, $w$ to, co stabilne i nieprzemijające.

Zainteresowanie Stachury semantycznym aspektem zjawiska rytmu oraz możliwościami wpływania na przebieg czytelniczej percepcji wykazuje wiele podobieństw z obserwacjami poczynionymi na ten temat przez Arthura Schopenhauera i Henriego Bergsona ${ }^{23}$. Obaj myśliciele - jako zwolennicy teorii kontemplacji - zwracali uwagę na jedną funkcję sztuki: na osłabianie przez nią wolicjonalnej aktywności jaźni podmiotu. Bergson konstatował:

Ibidem, s. 251. Z kategorią „Się” ściśle związana jest problematyka czasu i przemijania, do których przezwyciężenia Stachura nieustannie dążył. Jak zauważa P a c h o c ki (op. cit., s. 43), Heidegger był jednym z filozofów, którzy „przełamali [...] zdroworozsądkowe pojmowanie czasu” i stworzyli podwaliny pod ontologię fundamentalną. Wyniki jego obserwacji są w wielu momentach zbieżne z dociekaniami literackimi Stachury. Zob. też K. Ru t k o w s k i, Przeciw (w) literaturze. Esej o „poezji czynnej” Mirona Białoszewskiego i Edwarda Stachury. Bydgoszcz 1987, s. 213.

Interesujacym tropem badawczym byłoby także wskazanie na analogie w rozumieniu roli literatury, zwłaszcza poezji, przez Stachurę i Heideggera. Zob. m.in. M. Heid e gge r: Cóż po poecie. W: Budować, mieszkać, myśleć. Eseje wybrane. Wybór, oprac., wstęp K. M i c hals ki. Warszawa 1977 (przeł. K. Woli cki); O źródle dzieła sztuki. Przeł. L. Falki ewi cz. „Sztuka i Filozofia” 1992 , nr 5.

Zob. Wój cik, op. cit., s. 138.

21 M. Głow ińs ki, Zaświat przedstawiony. Szkice o poezji Bolesława Leśmiana. Warszawa 1981, s. 27. 
celem sztuki jest uśpi en i e aktywnych, czy raczej stawiających opór, sił naszej osobowości i doprowadzenie nas w ten sposób do stanu doskonałej uległości, w którym zrealizujemy ideę, jaką nam się sugeruje, albo przeżywamy uczucie analogiczne do uczucia wyrażonego ${ }^{24}$.

Środkiem w dużym stopniu warunkującym charakter doświadczenia estetycznego towarzyszącego poznaniu dzieła artystycznego jest właśnie rytm, nadający temu doświadczeniu wymiar niemalże hipnotyczny. Takie ujęcie pozwala przypisać sztuce walory terapeutyczne, traktować ją jako środek łagodzący cierpienia związane $\mathrm{z}$ odczuwaniem samego bytu. Znaczenie elementu rytmicznego w utworach artystycznych trafnie opisał Wójcik:

Eliminując wyostrzoną świadomość dystansu: odbiorca-nadawca, rytm w konsekwencji odgrywa rolę w e hikułu przenoszącego treści ponad potencjalnymi interpretacjami czytelnika, chroni przekaz przed zniekształceniem, warunkuje i wzmacnia siłę przeżycia estetycznego ${ }^{25}$.

Podobnie funkcję sztuki rozumiał Schopenhauer, uzależniając poziom satysfakcji estetycznej od stopnia zatracenia poczucia świadomości ,ja” odbiorcy. Wysuwane przez filozofa postulaty zatarcia granic wytyczanych przez pojęcia podmiotu i przedmiotu oraz wyeliminowania - z obcowania $z$ dziełem - wszelkich zakłóceń wnoszonych przez wolę, emocje i pragnienia odbiorcy mogły zostać w dużej części zrealizowane dzięki wykorzystaniu rytmu.

Niezwykle charakterystyczne dla postawy twórczej Stachury dążenie do poznania będącego wynikiem współdziałania zmysłów, intuicji, całego ciała i umysłu, do totalnego i bezpośredniego odczucia otaczającego świata ${ }^{26}$, znajdujące wyraz m.in. w koncepcji czasu literackiego czy w formie tekstów Steda ${ }^{27}$, przypomina nieco „romans z rzeczywistością, który stał się udziałem Mirona Białoszewskiego. Problem ten sygnalizował Tadeusz Nyczek:

H. B e r g s o n, O bezpośrednich danych świadomości. Przeł. K. B obrow s ka. W: I. W oj nar, Bergson. Warszawa 1985, s. 137. Podkreśl. A. A.

25 Wój cik, op. cit., s. 145. Podkreśl. A. A.

26 Taki sposób odczuwania świata może być pokłosiem uprzywilejowania wyobraźni mitycznej czy religijnej. Jak stwierdza M. Eli a de (Sacrum, mit, historia. Wybór esejów. Wybór M. C z e rw iński. Przeł. A. Tatarkiewicz. Warszawa 1970. Podkreśl. A. A.): „Mieć wyobraźnię - to znaczy widzieć świat w jego pełni”. Perspektywa ta korespondowałaby z niewątpliwa sympatią Stachury dla estetyki ekspresjonistycznej (inspiracje tradycją hymnu kościelnego, obrzędowością, silne zaangażowanie emocjonalne podmiotu tekstowego, nacechowanie etyczne wypowiedzi literackiej, nastrojowość apokaliptyczna). Zob. Szyngwelski, op. cit., s. 327.

Z. Trziszka (Edwarda Stachury zmagania z samym sobą. 〈Próba psychografii〉. „Miesięcznik Literacki” 1983, nr 7, s. 37. Podkreśl. A. A.) zauważył: „Stachura nieustannie pisał je dn ą i tę s a ma ks iąż kę, która była dzi ełem otwa r ty m". Odzwierciedleniem tej tendencji mogłaby być warstwa językowa dwóch eksperymentalnych opowiadań z tomu Się: Stuchanie oraz Iście. Na pierwsze z nich składają się 22 wersje zdania: „Się słuchało leżąc na koi bijącego w bulaj wiatru północnego”, materię drugiego opowiadania współtworzy zaś 21 wariacji na temat zdania: „Się szło powolutku skrajem drogi straszliwie i cudownie samotnym". Przypomina to nieco pomysł literacki A. Camusa wykorzystany w Dżumie - jeden z jej bohaterów przez wiele lat pisze książkę, której treść stanowi pewne bezustannie modyfikowane zdanie. Ważnym kontekstem jest tu także - odnawiany zarówno przez XIX-wiecznych „poetów wyklętych”, jak i przez chociażby B. Schulza - mit Księgi. Zob. K. Rut kow s k i, Próby wypowiedzi zupetnej. Wypowiedź zupełna. Wariant opisowy. W: Przeciw (w) literaturze, s. 219. 
Wydawało się: żyje, by pisać. Ale tak wówczas rzeczywiście było. Specyfika jego poezji i prozy polegała między innymi na tym, że jak rzadko który pisarz umiał Stachura przetworzyć w literaturę bądź co; każdy fragment egzystencji był godny zapisu. Nim programowo uczynił to Białoszewski (w prozie), pierwszy Stachura pisał d o n o sy rze c zywis to ś ci ${ }^{28}$.

Poza analogicznymi sposobami manifestowania rudymentarności, niegramatyczności i emocjonalności ${ }^{29}$ łączy tych dwóch twórców także pragnienie przezwyciężenia czasu pojmowanego linearnie. W chęci oddania „wiecznego teraz”, konstytuującego się na oczach czytelnika, Stachurze pomaga - respektujący równoległość zdarzeń - czas „infinitus”. Aluzje do zjawiska nieprzerywalnej jedności, opartej na trwaniu, pojawiają się m.in. w Całej jaskrawości:

Zapomniał ten albo ci, którzy wymyślili czasy proste i czasy złożone: praesens, imperfectum, perfectum, plusquamperfectum, futurum I, futurum II i inne czasy złożone, zapomnieli oni, którzy byli, więc są i będa, zapomnieli o jednym czasie, wi e c zy s ty m, infinitus. Który odmienia się tak: ja być, ty być, on być, my być, wy być, oni być. Ciepłe nasze oddechy, którzy jeszcze jesteśmy, i zimne teraz oddechy wszystkich, którzy byli, mieszają się ze sobą, całują i płyną razem po utartych szlakach i magistralach, i wszystkich dzikich rubieżach czasu i przestrzeni. To jest wi atr, nu rt ży w o ta, Lili Pons ${ }^{30}$.

Białoszewski często doprowadza do zakłócenia funkcjonujących mechanizmów językowych, aby osiągnąć postawiony sobie cel - polegający na „zanurzeniu” czytelnika wewnattrz dziejącej się rzeczywistości. Największą przeszkodę stanowi tu własność języka scharakteryzowana przez Włodzimierza Boleckiego:

[jest to] dyskretn ość (nieciagłość) znaków językowych wobec ciagłości rzeczywistości, którą znaki opisują, reprezentują, wyrażają. Konsekwencją dyskretności języka jest niemożność wyrażenia przez język kategorii równoczesności. [...] W języku równoczesność zdarzeń zostaje przełożona na liniową reprezentację słowną. Język nie tylko segmentuje rzeczywistość, ale i dokonuje selekcji oraz h i er a r c hi z a cji jej poszczególnych elementów. [...] ,język kłamie wzrokowi” (słuchowi, dotykowi) ${ }^{31}$.

Wspomniane analogie między koncepcją artystyczną Stachury a praktyka poetycką Białoszewskiego nie zacierają bynajmniej znaczących różnic, jakie daje się zauważyć, porównując postawy obu pisarzy. Autor Donosów rzeczywistości dążył głównie do zerwania $z$ konwencją w celu stworzenia własnej poetyki, mieszczącej się jednak w „granicach literatury”. Stachura natomiast występował przeciw literaturze jako tandetnej atrapie życia i martwej rejestracji bogactwa rzeczywistości ${ }^{32}$.

T. Nyczek, Życiodajny, śmiercionośny. „Miesięcznik Literacki” 1980, nr 1, s. 59. Podkreśl. A. A. Odnosząc się do wypowiedzi Nyczka, na prekursorski charakter „totalizujących” idei Białoszewskiego wskazuje Pachocki (op. cit., s. 34-35, 37) i przypomina, że ich powstanie można datować już na 1956 r. (Teatr osobny z tomu Obroty rzeczy). Warto zauważyć, iż gest „spisania wszystkiego" zyskał dużą popularność w kręgu polskich twórców, o czym wspomina R. Ny c z (Sylwy współczesne. Kraków 1996, s. 44): „Spiszę wszystko“, powiadają zgodnie Buczkowski i Białoszewski, "chcę wszystko zatrzymać". "Wszystko", czytamy u Różewicza [...] - bo wszystko jest warte utrwalenia, odsłaniającego literacki walor "każdego drobiazgu".

Zob. Szyngwels ki, op. cit., s. 288.

Sta chura, Cała jaskrawość, s. 20. Podkreśl. A. A.

W. Bolecki, Poetycki model prozy w Dwudziestoleciu międzywojennym - Witkacy, Gombrowicz, Schulz i inni. Studium z poetyki historycznej. Wyd. 2, popr., uzup. Kraków 1996, s. 199. Podkreśl. A. A.

Zob. P. Mich hałow s ki, Źródła i ujścia „poezji czynnej”. „Nowe Książki” 1988, nr 5, s. 55. 
Nieufność Steda wobec instytucji literatury ${ }^{33}$ i - przede wszystkim - języka ma ścisły związek $\mathrm{z}$ jego przemyśleniami na temat mechanizmu powstawania znaczeń w obrębie kultury europejskiej, z refleksją nad problemem reprezentacji. Człowiek-nikt, podzielając niewątpliwie stanowisko samego autora, konstatuje:

Co znaczy mistyka? Moglibyśmy zajrzeć raz do jakiegoś słownika [...], ale chyba tylko po to, żeby się dowiedzieć, że się niczego z nich nie dowiemy. Bo ws zystkie słowniki tłumaczą to samo przez to samo. Szuka się pod hasłem: mistyka, wyjaśnienie brzmi: nadzmysłowość, nadprzyrodzoność; szuka się pod hasłem: nadprzyrodzoność, wyjaśnienie brzmi: mistyka. Tak to wygląda, i to w wielkim, oszczędnym skrócie. Człowiek sfabrykowany z papieru zadowoli się tym, że trochę papieru przeżuł, nakarmi się tym i będzie dalej tym karmił się. Ale człowiek uważny, z krwi i kości, zwymiotuje to i więcej się na to nabrać nie da. Prawidłowo, poprawnie słowniki winny nazywać się: ta u to log iar ze $\mathrm{e}^{34}$.

Nieadekwatność tradycyjnego sposobu ujmowania rzeczywistości najwyraźniej dochodziła do głosu poprzez zestawienie z obcym kontekstem kulturowym. Ernest Fenollosa, autor eseju The Chinese Characters as a Medium for Poetry (opublikowanego po jego śmierci przez Ezrę Pounda), wskazywał na zalety języków ideograficznych, poddając krytyce zachodni sposób definiowania:

Definicja europejska jest zawsze ucieczką od rzeczy prostych, które definiujący doskonale zna, w rejony nieznanego, to znaczy w rejony coraz bardziej i bardziej odległej abstrakcji.

Jeśli zatem pytasz, co to jest czerwień, Europejczyk odpowiada, że to kolor.

Jeśli pytasz, co to jest kolor, mówi, że drgania lub refrakcja światła, lub efekt rozszczepienia widma.

Jeśli zaś pytasz, co to drgania, odpowiada, że przejaw energii lub przejaw czegoś tam - i w końcu dochodzi do sposobu istnienia (lub nieistnienia) bytu. W każdym razie do miejsca, w którym obaj nie czujecie już gruntu pod nogami ${ }^{35}$.

Oczywiście Sted nie miał prawdopodobnie świadomości istnienia związków między jego sposobem użycia języka a struktura języków ideograficznych, nie wnikał w naturę owego mechanizmu k o n w e r g e n c j i ${ }^{36}$. Nie zmienia to jednak faktu, że czerpał - intuicyjnie - z metod wzbogacania znaczeń, o których wspomina się w ABC czytania ${ }^{37}$.

Z pewnością większą ufność poety wzbudziłaby Derridiańska koncepcja literatury, rozumianej nie tylko jako przestrzeń zinstytucjonalizowanej fikcji, ale także jako fikcyjna instytucja, która - zmierzając do przekroczenia samej siebie - z zasady pozwala powiedzieć wszystko. Zob. Ta dziwna instytucja zwana literatura. Z Jacquesem Derrida rozmawia Derek Attridge. Przeł. M. P. Markow ski. „Literatura na Świecie” 1998, nr 11/12, s. 180.

St a c hura, Fabula rasa, s. 60-61. Podkreśl. A. A.

E. F e nollos a, The Chinese Characters as a Medium for Poetry. Cyt. za: E. P o u n d, ABC czytania. Przeł. K. B is k u p s ki. W zb.: Nowa krytyka. Antologia. Wybór H. Krze c z k ow s ki. Wstęp, oprac. Z. Ła piński. Warszawa 1983, s. 43. E. Sta chura znał tekst Pounda, czego potwierdzeniem jest chociażby cytat z tego utworu pojawiający się w jednym $z$ felietonów ze zbioru Wszystko jest poezja. Opowieść-rzeka (Warszawa 1975), zatytułowanym W labiryncie świata bez wijacej się nitki Ariadny cytatów ciag jak wędrowny ptaków klucz.

36 D e r rid a (Ta dziwna instytucja zwana literatura, s. 202) określa wspominane tu zjawisko mianem „paradoksalnej historyczności”, odnosząc je do sytuacji, gdy „Pisarz może być nieświadom swojego stosunku do tradycji historycznej, która go kształtuje lub która przekształca, wynajduje, przemieszcza”.

37 Pound wyróżnił trzy sposoby wzbogacania znaczeń, jakie można przenieść do języka zachodniego bez uciekania się do definiowania słów poprzez inne słowa: fanopea (gdy intensyfikuje się semantykę języka, narzucając wyobraźni wzrokowej przedmioty); melopea (gdy budzi się emocje za po- 
Na dorobek prozatorski Stachury wpłynęła także w dużym stopniu literatura iberoamerykańska. Miał on okazję zapoznać się z twórczością hiszpańskiego kręgu kulturowego niejako z pierwszej ręki, zajmował się też jej tłumaczeniem. Przełożył wiersze Jorgego Luisa Borgesa ${ }^{38}$ i opowiadania Juana Carlosa Onettiego ${ }^{39}$. Wśród rękopisów poety znajduja się również niepublikowane przekłady opowiadań Julia Cortázara (z tomu Ostatnia runda) oraz powieści Sto lat samotności Gabriela Garcíi Márqueza ${ }^{40}$. Istotną inspiracją dla Stachurowej koncepcji czasu literackiego mogły być osiagnięcia artystyczne Borgesa, który umiejętnie wskazywał w swoich utworach na pozaczasowość zdarzeń:

Zgiełk placu zostaje za mna i wchodzę do Biblioteki. W niemal fizyczny sposób odczuwam grawitację książek, pogodny nastrój ładu, czas, na którym dokonano sekcji i magicznie zakonserwowano [...]. Przypominam sobie, że w tym miejscu już kiedyś przyszła mi na myśl ta retoryczna figura i potem inne określenie, które również definiuje kontur, ,jałowy wielbłąd” z Pieśni do Księżyca, i potem heksametr, ten z Eneidy, w którym użyta jest ta sama figura, w sposób jeszcze doskonalszy: „Ibant obscuri sola sub nocte per umbras”. [...] Wchodzę; [...] wręczam panu tę książkę. Jeżeli sam siebie nie oszukuję, to pan, Lugones, nie czuł do mnie niechęci i byłoby panu przyjemnie, gdyby jakiś mój tekst zyskał pańskie uznanie. [...] przewraca pan kartki i z aprobatą odczytuje jakiś wiersz [...]. W tym miejscu rozpuszcza się mój sen, jak woda w wodzie [...]. Tak to jest (mówię sobie), lecz jutro ja też umrę i pomieszają się nasze czasy, i kolejność dat i zdarzeń zgubi się w sferze symboli $[\ldots]^{41}$.

Znajomość spuścizny autorów z kręgu kultury iberoamerykańskiej mogła ponadto zdeterminować zainteresowanie Steda zjawiskiem „centonizacji”. Co istotne, gatunek centonu - „będący wytworem schyłkowej literatury epoki bizantyjskiej [...], kształtowany $z$ urywków [...], posiadający własną poetykę normatywną [...]" i stanowiący przykład związków tekstowych oraz swoisty rezultat intertekstualności ${ }^{42}$ - zostaje u Stachury przystosowany do prezentacji wyimków pochodzacych w znacznej mierze od niego samego (bądź jego alter ego literackich). Najbardziej autointertekstualny utwór Steda to Wszystko jest poezja, w którym pojawiają się dwa eseje zbudowane na podobieństwo centonu (W labiryncie świata bez wijacej się nitki

mocą dźwięku i rytmu wypowiedzi); logopea (oba efekty jednocześnie). Zob. W ój cik, op. cit., s. 293-294.

38 J. L. Borges, Antologia osobista. Przeł. E. Stachura, A. Sobol-J urczykowski, Z. Chadzyńs ka. Kraków 1974.

39 J. C. O n e t ti, Historia kawalera z różą i ciężarnej dziewicy z Liliputu. Przeł. R. Ka li c k i, E. S t achura. Warszawa 1977.

40 Rękopisy znajdują się w Muz. Lit. (inw. 2556).

41 J. L. Borge s, Dla Leopolda Lugones. W: Antologia osobista, s. 64. Podkreśl. A. A. Hipotezę Ru tkows kiego (Próby wypowiedzi zupełnej, s. 222), że koncepcja „wypowiedzi zupełnej” została przez Stachurę zaczerpnięta od Borgesa, mógłby potwierdzać chociażby następujący fragment z opowiadania argentyńskiego twórcy Alef (w: Alef. Przeł. Z. C hą d zyń s ka, M. P o tok - Ny c z. Warszawa 2003, s. 177-178. Podkreśl. A. A.): „W tym bezmiernej wielkości momencie ujrzałem miliony zdarzeń przecudownych i straszliwych; nic jednak nie zdumiało mnie tak, jak to, że wszystkie one zajmowały to samo miejsce, ani nie nakładając się na siebie, ani nie będąc przezroczyste. Wszystko, co ujrzały moje oczy, było równoczesne - to, co opiszę, będzie sukcesywne, bo taką ma naturę język. Mimo to coś niecoś udało mi się uchwycić”.

42 T. Cieślikowska, Tekst intertekstualny. Tekst - kontekst - intertekst (sytuacje graniczne). W: W kręgu genologii, intertekstualności, teorii sugestii. Warszawa-Łódź 1995, s. 103. 
Ariadny cytatów ciag jak wędrowny ptaków klucz ${ }^{43}$ i W labiryncie świata z niewyraźnie wijacą się nitką Ariadny cytatów dalszy ciag jak wędrowny ptaków klucz ${ }^{44}$ ). Na zawartość tych esejów składają się fragmenty książek różnych autorów, a między owymi fragmentami występują quasi-cytaty wygłaszane przez bohaterów-narratorów dzieł prozatorskich Stachury: przez Edmunda Szeruckiego i przez Janka Praderę.

Do pozostałych esejów $\mathrm{z}$ tego zbioru - przypominających swoją konstrukcją raczej opowiadania - można zastosować określenie „centonowa mowa”, które odnosi się do praktyki przeplatania dzieł literackich przytoczeniami różnego rodzaju odcinkami innych tekstów: cytatami, parafrazami, pastiszami, ogólnie rzecz biorąc: zapożyczeniami ${ }^{45}$. Owe zapożyczenia mają u Stachury bardzo często charakter autocytatów (z wierszy, piosenek, opowiadań, powieści, tłumaczeń) i pełnią funkcję cyklotwórczą ${ }^{46}$. Ostatecznie więc, pisząc przez całe życie jedną i tę samą książkę ${ }^{47}$, poeta najchętniej korzystał z zasobów własnej twórczości, która stanowiła najbardziej adekwatną realizację jego koncepcji artystycznych. Można przypuszczać, że dystans, z jakim autor Całej jaskrawości odnosił się do szukania powinowactw między idiomem Márqueza a chociażby tym Jamesa Joyce’a, przenikał także do przemyśleń Stachury na temat własnego dorobku i prób jego interpretacji:

O literackich modelach Márqueza mówią krytycy, że są nimi: Joyce, Virginia Woolf i William Faulkner. Ale i to, jak prawie wszystko u krytyków, szyte jest grubą nicią. Jest pis arz, wi ę c nale ży mu wynaleźć drzewo genealogiczne. A ponieważ pisarz jest znakomity, więc odpowiednio i gałęzie czy lepiej konary genealogiczne drzewa winny być znakomite. Więc: Joyce, Virginia Woolf, William Faulkner. Tak jakby nie można było zwyczajnie stwierdzić, że Gabriel García Márquez jest po prostu jedyny w swoim rodzaju. Jak jedynymi sa: Joyce, Woolf, Faulkner czy Onetti, Lezama Lima, Lautréamont, Leopold Buczkowski, by wymienić kilku ze sporej liczby jedynych ${ }^{48}$.

Nietrudno zatem zauważyć, że - poszukując istotnych dla Stachury źródeł inspiracji - sprzeniewierzyłam się intencji autora. Podjęcie próby scharakteryzowania jego dokonań w świetle tradycji literackiej i filozoficznej - zwłaszcza przy uwzględnieniu mnogości nawiązań, z jakimi mamy w tym przypadku do czynienia - było jednak nieuniknione ze względu na niepodważalność tezy o ścisłej relacji sztuki i otaczającej rzeczywistości. Takie ujęcie nie stoi, rzecz jasna, w sprzeczności $z$ przekonaniem o silnym nasyceniu prozy Stachury pierwiastkiem indywidualnym, który - zgodnie $z$ twierdzeniem Jacques'a Derridy - może w pełni dojść do głosu wyłącznie w wyniku otwarcia się na historię, kontekst i gatunek ${ }^{49}$.

E. S t a c h u r a, W labiryncie świata bez wijacej się nitki Ariadny cytatów ciagjak wędrowny ptaków klucz. W: Poezja i proza. Red. K. Rutkow ski. T. 4. Warszawa 1975.

E. S t a c h u ra, W labiryncie świata z niewyraźnie wijaca się nitka Ariadny cytatów dalszy ciag jak wędrowny ptaków klucz. W: jw.

Zob. T. Ci e śli k ow s k a, Centon i centonowa twórczość. W: W kręgu genologii, intertekstualności, teorii sugestii, s. 155.

Zob. Pa ch ocki, op. cit., s. 161-169.

Zob. E. Sta chura, Miłość, czyli życie i zmartwychwstanie Michała Katnego, zaśpiewana, wypłakana $i$ w niebo wzięta przez edwarda stachurę. W: Poezja i proza, t. 5 (1982), s. 384: „Jedna książkę w życiu można napisać [...], jedną piosenkę ułożyć, raz się zakochać i jednym życiem żyć, jednotorowym. Ponadto [...] wszystko jest rozpusta".

St a ch ura, rękopis. Cyt. za: Pa c h ocki, Stachura totalny, s. 21. Podkreśl. A. A.

Zob. Ta dziwna instytucja zwana literatura, s. 217 (ostatnie podkreśl. A. A.): „Absolutna, absolut- 


\section{Abstract \\ ANNA AL-ARAJ Jagiellonian University, Cracow \\ EDWARD STACHURA'S PROSE WRITINGS IN THE LIGHT OF LITERARY AND PHILOSOPHICAL TRADITION}

The present article ponders upon the connections between Edward Stachura's selected ideas developed in his prose pieces and the reflections of Western European, American and Latin-American philosophers and men of letters (e.g. Arthur Schopenhauer, Henri Bergson, Ralph W. Emerson, Martin Heidegger, Adam Mickiewicz, Miron Białoszewski, Jorge Luis Borges). Indications of the dependencies and affinities allow to place Sted's creativity - difficult to classify due to its autonomy - in a broader cultural context and to show its phenomenon as a consequence of solutions practiced earlier by other authors.

nie czysta jednostkowość, jeśli taka istnieje, nigdy by się nie mogła ujawnić, a przynajmniej nie byłaby dostępna w czytaniu. Czytelność uwarunkowana jest podziałem, u czestnictwem i przynależnością. Tak więc dzieli się ona i bierze udział w gatunku, rodzaju, kontekście, znaczeniu, pojęciowej ogólności znaczenia etc. Zatraca się, by się zaprezentowa ć”. 